\title{
INFLUENCE OF FINANCIAL TECHNOLOGY (FINTECH) ON FINANCIAL INDUSTRY
}

Ismail Musabegovic ${ }^{1}$, Mustafa Özer ${ }^{2}$, Sladjana Djukovic ${ }^{3}$, Stefan Jovanovic ${ }^{4}$

*Corresponding author E-mail: ismail.musabegovic@bba.edu.rs

A R T I C L E I N F O
Original Article
Received: 01 December 2019
Accepted: 12 December 2019
doi:10.5937/ekoPolj1904003M
UDC 336:004

Keywords:

Financial Technology, Banking, Disruption, Efficiency, Regulation.

JEL:G00, 0330

\section{A B S T R A C T}

The financial technology (hereinafter: fintech) industry is growing rapidly which is supported by the fact that it received more than $\$ 20$ billion in investment last year alone. This article surveys historical development of fintech and its influence on market structure in banking industry, efficiency, strategic plans of participants, and stability of financial market. Based on World Bank database, the paper tests the fundamental premise - whether there is a relationship between country GDP and population and usage of new technology and smartphones in financial transactions and payment processing.

The results of the study provide evidences of statistically significant positive relationships between per capita GDP and usage of new technology and smartphones in financial transactions and payment processing. Also, they indicate statistically significant positive relationships between per capita GDP and payment of utilities and received wages through a mobile phone. Thus, the results of study should be taken into consideration when forming the policies regarding the use of new technology and smartphones in financial transactions and payment processing.

C 2019 EA. All rights reserved.

\section{Introduction}

In the past, the financial market was strictly divided between players like banks, insurance companies, private hedge and equity funds etc. The technology rapid develop and drastically alter the Internet (Angeloska-Dichovska \& Petkovska-Mirchevska,

1 Ismail Musabegovic PhD, associate professor, Belgrade Banking Academy, Zmaj Jovina 12 Belgrade, Serbia, ismail.musabegovic@bba.edu.rs +381 63 525150, https://orcid.org/00000001-8137-8918

2 Mustafa Özer PhD, full professor, Anadolu Üniversitesi: Eskisehir, Turkey, +90 (222) 335 0580 / 3373 https://orcid.org/0000-0001-9852-8441

3 Sladjana Djukovic B.Sc Econ. M.Sc. Econ. Banker, Sberbank AD Belgrade, Serbia, sladjanadjukovic@yahoo.com,+381 693 93240, https://orcid.org/0000-0002-5043-9869

4 Stefan Jovanović B.Sc Econ. M.Sc. Econ. CFO, Balkan Polymers, Serbia, steffy_jov@, hotmail.com, +381 60 2229848, https://orcid.org/0000-0003-2797-3016

http://ea.bg.ac.rs 
2017). The most important fact was that this market remained largely unaffected. But recently this all changed with the breakthrough of the companies that use technology for different financial solutions such as banking, payments, and personal financial management. These firms are called fintech firms.

Fintech refers to financial services based on new processes and products that become available thanks to digital technological advancements. More precisely, the Financial Stability Board defines fintech as "technologically enabled financial innovation that could result in new business models, applications, processes or products with an associated material effect on financial markets and institutions and the provision of financial services".

"The main areas where fintech companies are expending rapidly, according to European economy banks, regulation, and the real sector publication (Pazzolo, 2017) are:

- $\quad$ Payment systems (payments, clearing and settlement);

- Funds management (deposit, lending, capital raising and investment management);

- Insurance.

All services mentioned above are typically offered by banks, who are assumed as traditional financial institutions. But the main reason why fintech companies are able to impact on these services comes from cost reductions implied by digital technology advancements, improved and new products for clients and limited burden from regulators. European economy banks, regulation, and the real sector publication Pazzolo, (2017) defines that, with technological advancements, fintech operators benefit from:

- Lower costs of search that enable more effective matching in financial markets,

- Economies of scale in collecting and manipulating large bunches of data,

- Cheaper and more secure transmission of information,

- Lower costs of verification."

According to Pierrakis and Collins (2013): "Such innovations can disrupt existing industry structures and blur industry boundaries, facilitate strategic disintermediation, revolutionize how existing firms create and deliver products and services, provide new gateways for entrepreneurship, democratize access to financial services, but also create significant privacy, regulatory and law enforcement challenges"

\section{Fintech worldwide}

Having in mind that this is a new field, there is no official agreement or segmentation of this industry. Based on Dorfleitner et al. (2017) "companies in the Fintech industry can be divided into four major segments in accordance with their distinctive business models": 
Figure 1: Segments of the Fintech industry

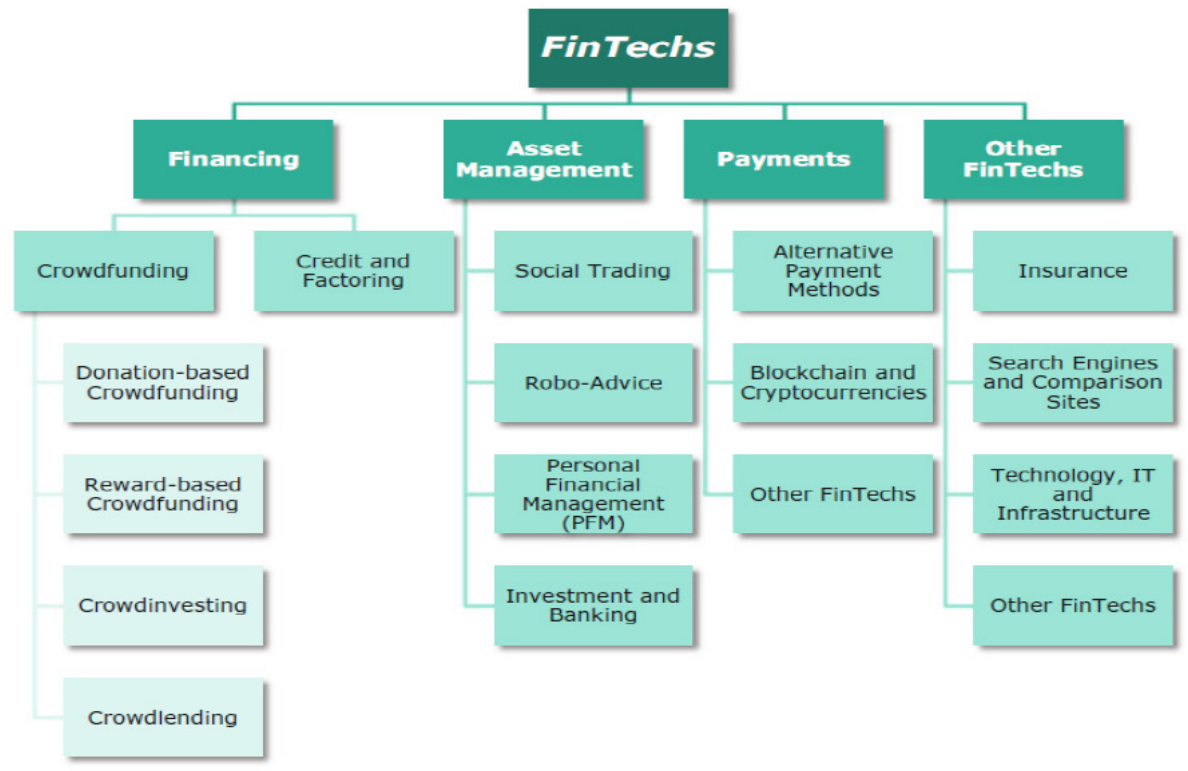

Source: "Fintech In Germany” Dorfleitner, G., Hornuf, L., Schmitt, M., Weber, M

The number of new companies this industry in period 2008-2010 was modest, but in the period of 2011-2014 the total number of companies more than doubled:

Figure 2: Fintech companies founded by year, 2008-2017

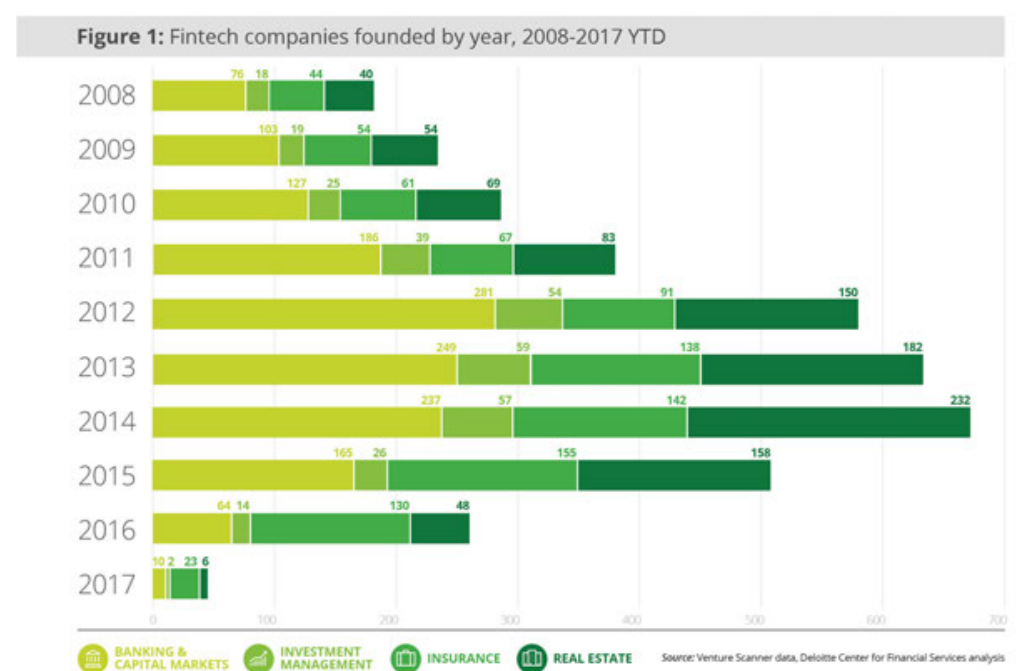

Source: Venture Scanner data, Deloitte (2018)

In the graph above we can observed that not all fintech categories have generated the same number of startups. Deloitte analysis (Fintech by the numbers) points out that "within banking and capital markets, payments is the clear leader, followed by deposits http://ea.bg.ac.rs 
and lending and financial management. The study also confirms the impact of the growth in robo-advisors, as investment management fintechs are also relatively large in number".

Figure 3: Number of companies by category
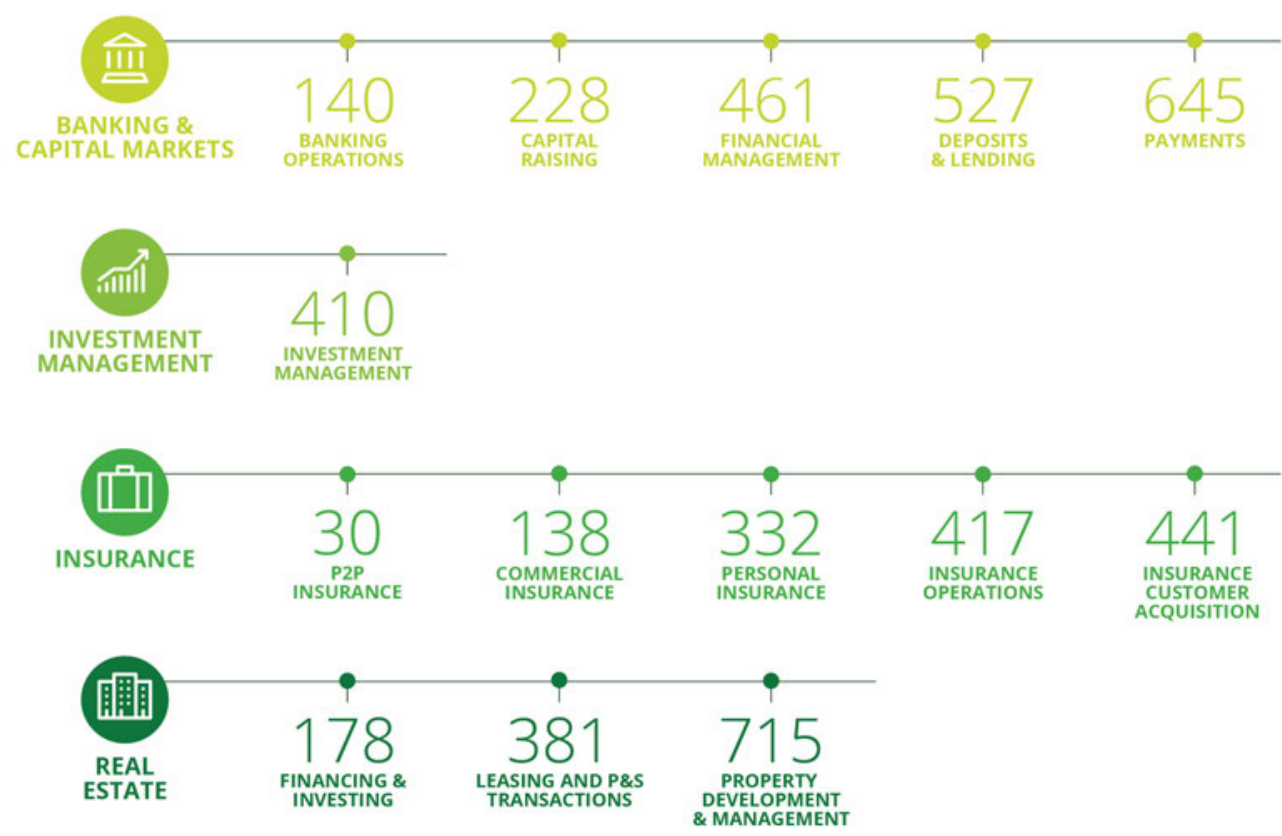

Source: Venture Scanner data, Deloitte (2018)

Despite the global expansion and worldwide presence, there are cities in the world that are considered to be IT hubs and homes of largest part of fintech companies:

Figure 4: Global Fintech hubs

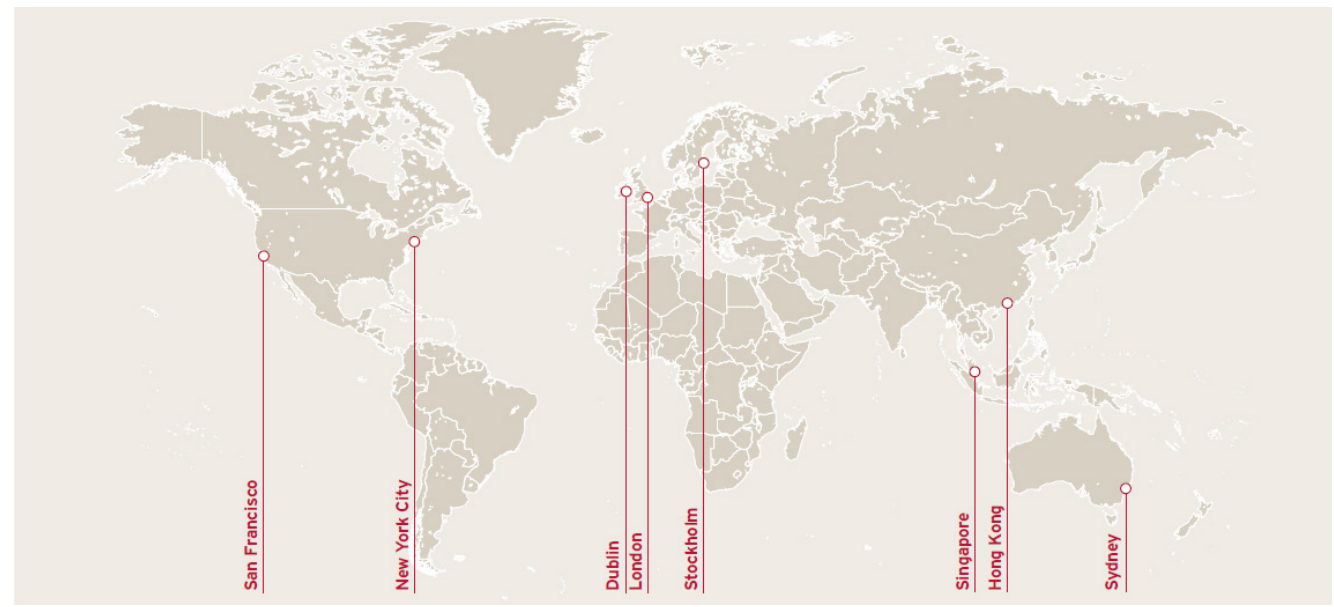

Source: Fintech in CEE, Deloitte 


\section{Banks and fintech - symbiosis}

The growth of claims of the Banking Sector and the decline in the International Investment Position of the Republic of Serbia is conditioned by the illiquidity of the public sector (Durkalić \& Ćurčić, 2019). Authors Furtula, Todorović \& Durkalić (2018) concluded that performance of banking sector increased and changed in period 2008 to 2016.

By definition, banks are financial institution licensed to receive deposits and make loans. In order to do this, they have to perform three activities:.

- $\quad$ Transforming the features of financial assets and liabilities

- $\quad$ Providing payment services,

- $\quad$ Gathering and interpretation data

The first function is related to maturity transformation, the practice by financial institutions of borrowing money on short terms and then lending money out. This function is very important to economic system, since it provides long term investments which lead to increasing productivity of one country. As main provider of liquidity to their customers, banks are also well placed in offering payment services. Data gathering and interpretation includes all the activities related to clients and their needs, monitoring of their behavior, with main goal to create and manage a diversified portfolio that will maximizes the return and the bank's earnings. Banks also provides a lot of other services; such as Investment management, M\&A advice, security underwriting and brokerage, but three activities mentioned above consider being core of banking business and crucial for banks' existence.

In order to understand the influence of Fintech on the banks and the whole industry, we need to look deeper into each of these three key activities of the bank. According to a survey conducted by PWC between banks and other participants on financial market, the main financial activities that are already conducted by their customer with fintechs are payments and fund transferring: 
Figure 5: The main financial activities conducted with fintechs

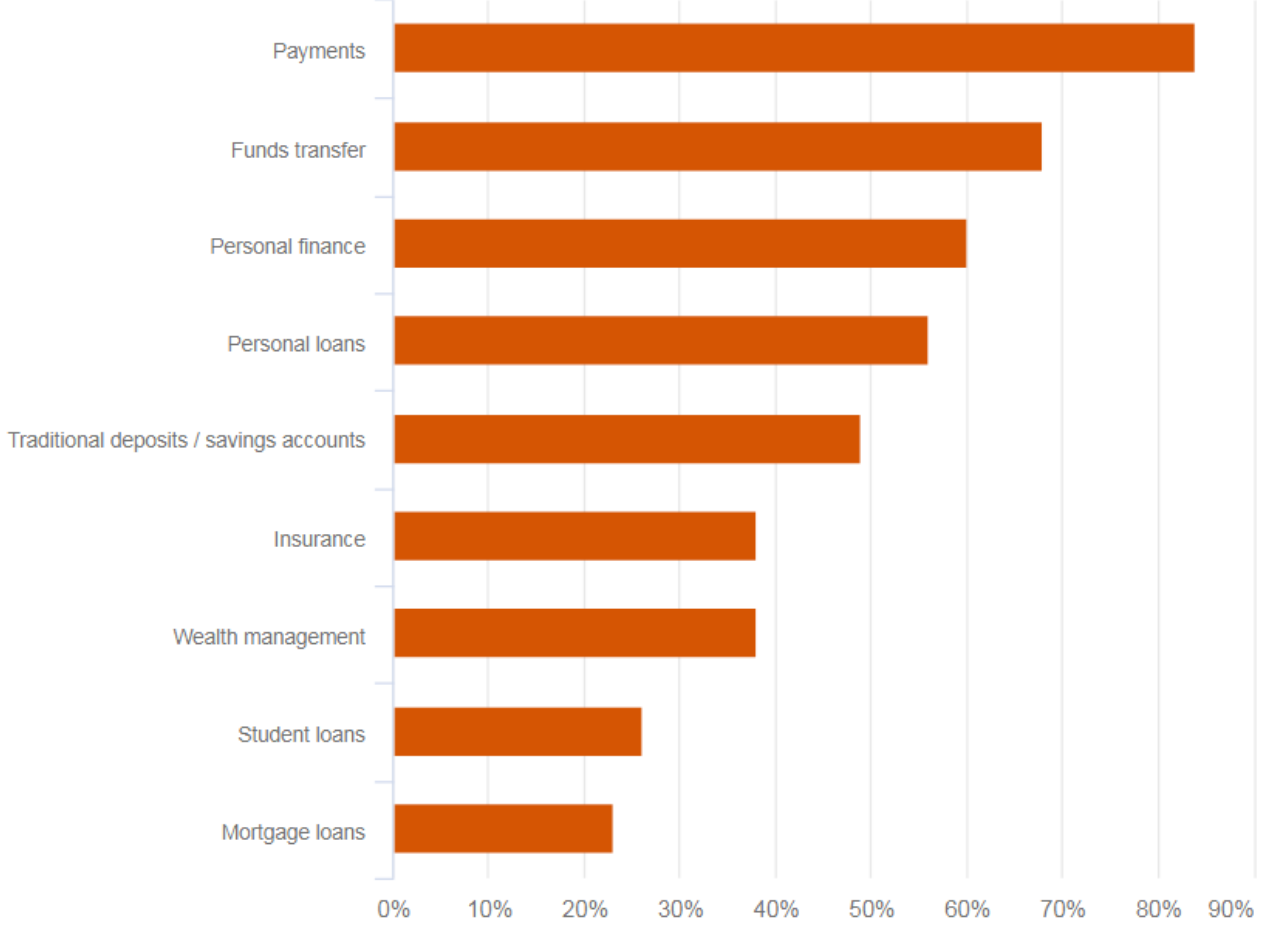

Source: PwC's Global Fintech Survey, 2017

This also coincides with the fact that the lending, payment systems and information processing are the main areas of development in the application of digital technology, which leads us to conclude that these are the main areas where we can see influence and impact from fintech companies on banking industry.

\section{Transforming the characteristics of financial assets and liabilities}

We have to repeat one more time that one of the main tasks of banks is transforming the maturity characteristics of financial assets and liabilities. According to the article from Pazzolo in 2017 through maturity transformation banks use short term deposits and based on them grant long term loans. This is essential in providing liquidity services to clients.

In this segment of business, the main advantage of fintech is possibility to lower the intermediation costs and increase access of unserviced parts of the population and less developed countries to financial services. The biggest advantage of these companies lies in the fact that they can overcome information asymmetries, which are one of the main stones of the banking industry. According to PWC survey, when working with traditional financial companies, the main challenges that customers are facing with are difference in management and culture and regulatory uncertainty: 
Figure 6: The main challenges working with traditional financial companies

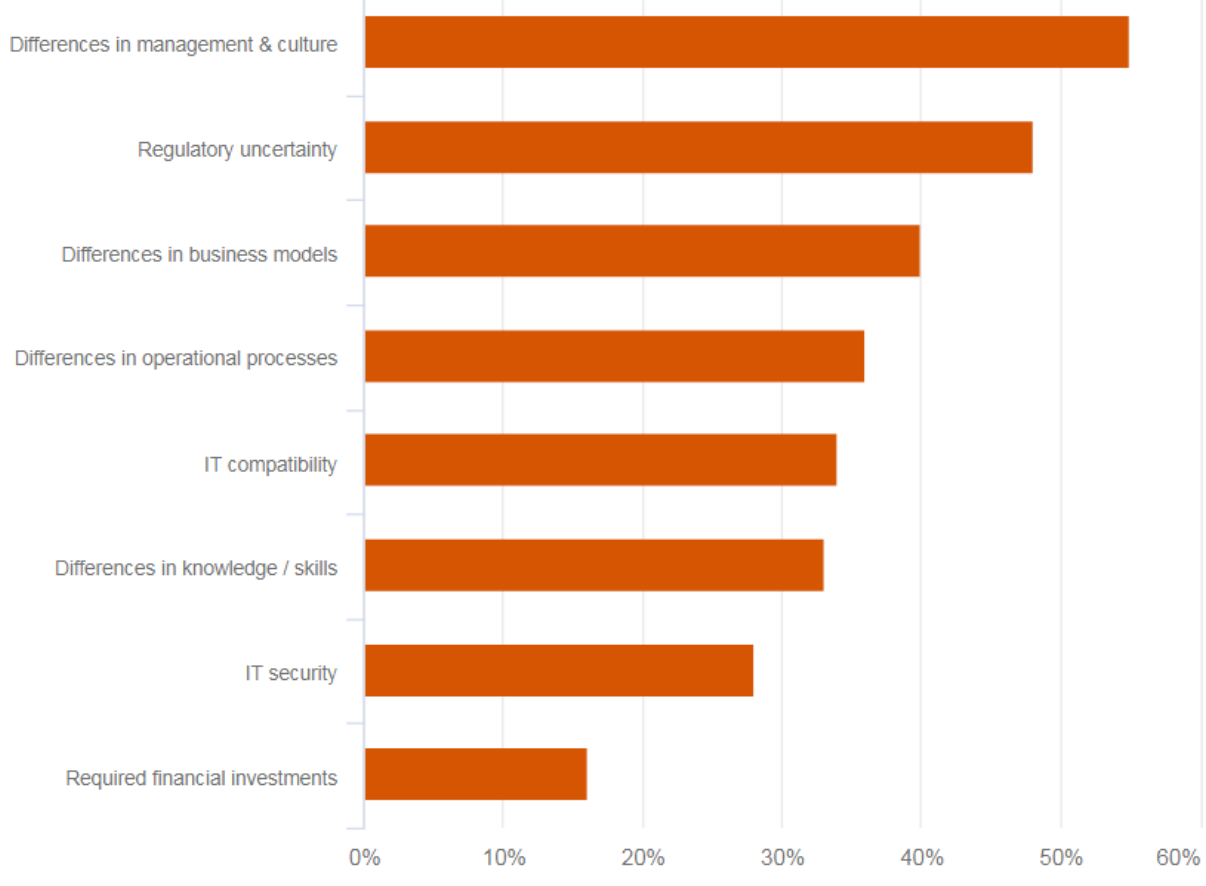

Source: PwC's Global Fintech Survey 2017

Having in mind that they have no legacy technology to deal with, fintech companies have larger innovation capacity than traditional financial institutions like banks.

Online alternative financing platforms are one of the ways that fintech companies approach this part of the banking business. Known as Crowd funding, these solutions are consider to be one of the fastest growing industries developments in recent years.

\section{Peer-to-peer (P2P) lending}

As substitutes in providing credit, peer-to-peer (P2P) lending platforms connect people looking to invest money with potential borrowers who need loans for their business. They perform the role of an intermediary, matching borrowers and lenders directly and transfer money between them. Because there's no traditional financial institution acting as a middleman, and therefore none of the overheads associated with banking, parties in this agreement could benefit from more favorable interest rates.

Also, based on Bruton et al. 2014 "peer-to-peer lending can also include platforms similar to micro financing in that individuals directly provide capital to other individuals". 
Figure 7: The way how P2P works:

\section{Value Exchange between Borrowers and Lenders}

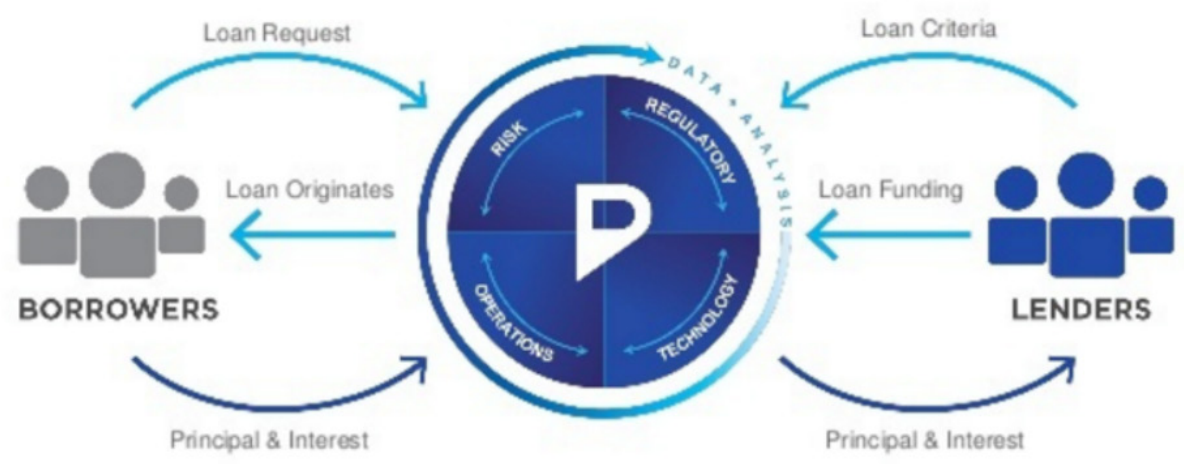

Source: Kate J.; (2019) - What do investor should look before investing in p2p lending Available data from Kate (2019) show that "fintech credit activity has expanded rapidly in many countries over recent years. Estimates from the CCAF indicate that $\$ 284$ billion in such credit was extended globally in 2016, up from \$11 billion in 2013. In absolute terms, China was by far the largest market in 2016; the United States and the United Kingdom followed at a distance, with other large advanced economies further behind." According to PWC survey in 2016, the potential market indicates that the projected market of P2P market in USA will be USD150 billion by 2025 .

Figure 8: The expansion of fintech credits:

Global volume of new fintech credit

USD bn

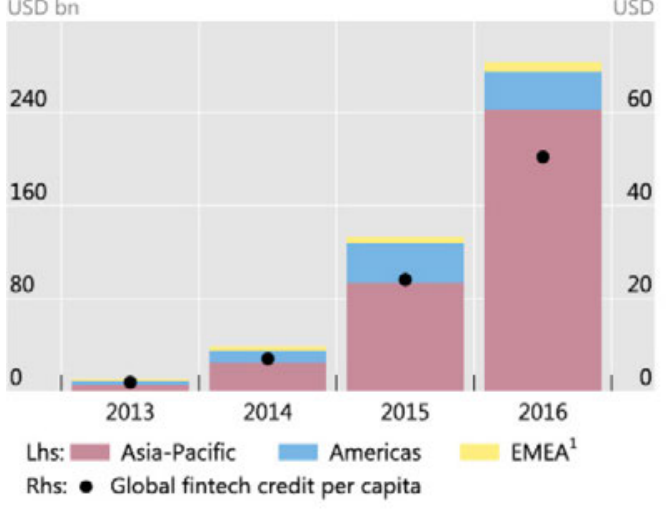

\section{Fintech credit volumes, selected countries ${ }^{2}$}

Q1 $2016=100$

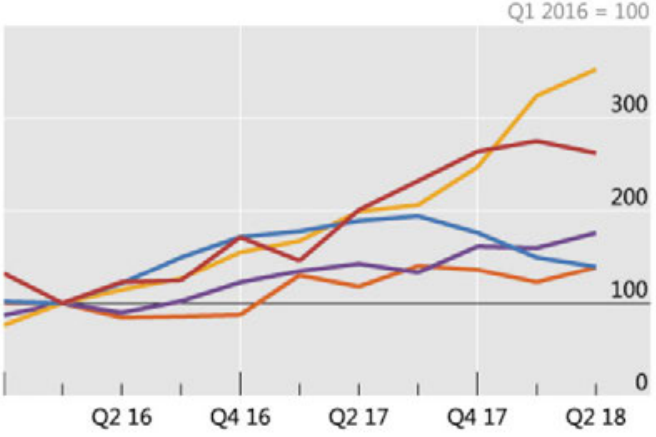

- Australia \& New Zealand - China

- Europe (excl GB) Zuland - United Kingdom - United States

${ }^{1}$ Europe, Middle East and Africa. ${ }^{2}$ Data are based on two platforms for Australia and New Zealand, all platforms covered by WDZ.com for China, 32 platforms for Europe, 30 for the United Kingdom and six for the United States.

Source: BIS - Fintech credit markets around the world 


\section{Equity Crowd Funding (ECF)}

Equity crowd funding (ECF) is similar to stock investment. It is a mechanism that enables broad groups of investors to provide funds for small businesses and startup companies in return for equity. The potential reward of this type of investment includes capital gain (if investors sell shares) and dividend, while risk is the bankruptcy of company and losing all the invested funds. This mode of Fintech firms used to be limited to venture capitalists and angel investors.

Based on Cumming \& Zhang (2016) ECF has provided the small investors good opportunity to equity investing in private companies. A smaller size of the companies involved in these platforms in comparison to those typically associated with a public securities offering considered as a great addition of these platforms, it provides investors and entrepreneurs an access to an online marketplace where they can change ownership stakes for new financing.

Bearing in mind new ways of transforming the characteristics of financial assets and liabilities, the main question is whether these new Fintech players can provide the same level and quality of service as banks do.

The answer to this question is very difficult to determine. Fintech company can collect money and put them in a pool, from which borrowers can make withdrawals when needed. New technologies that are developed by fintech firms enhance efficiency in this process, while banks are cannot adopt new technologies so quickly due to the regulatory requirements. Because of that, banks rely on old IT infrastructure systems, which gives fintech firms competitive advantage. One of the main potential advantages of the new entrants in these market lies in using the mistrust that millennials have towards banks at the same time that they offer digital services with which the younger generation is at ease.

An opposite look at the Fintech asserts that advances in financial technology have failed to reduce intermediation costs. Certain studies from Federal Deposit Insurance Corporation indicate that Fintech lenders in fact offer higher interest rates than nonFintech lenders. Based on Pazzolo, 2017, "two competitive advantages of retail banks which may be eroded by the new entrants are:

- $\quad$ banks can borrow cheaply with their access to cheap deposits and explicit or implicit insurance by the government, and

- $\quad$ they enjoy privileged access to a stable customer base that can be sold a range of products".

The presence of deposit insurance can make it easier for new competitors to enter this market as banks, but in this case participants will have to pay for the banking license and compliance expenditures.

Due to maturity transformation, banks also separate each loan they lend from funding of each individual depositor, thus obtaining a much better portfolio diversification than what 
a single depositor can achieve. New solutions like peer-to-peer (P2P) or crowd funding lending cannot offer any diversification to potential investors. If they do, then platforms will have to take some of their risk on their books (hence, subject to banking regulations) or act as issuers of securities (and then become subject to security regulations).

These facts indicate that entering into an intermediary business with new technologies will largely depend on how regulation and government guarantees are applied. As far as banks also adopted new information management technologies and regulatory arbitrage is excluded, the threat to their business from this channel seems limited.

\section{Providing payment services}

Banks, together with credit cards providers such as Visa and MasterCard, are still the owners of transactional payments market. It is not a secret that customers facing liquidity issues can benefit from making payments directly from deposit account, and this is supported by some strong economies.

The unexpected thing here is that this need of customers is more and more covered by nonbanks such as PayPal, Apple, Google, Amazon etc.

Number of non-banking financial companies are emerging, from payment institutions to electronic money providers. In some countries, also non-financial corporation, such as telecommunication companies, are entering the market of payment services, taking advantage of its large customer base.

Not only that new payment providers are entering the scene, but disruption of known payment systems can also be caused by crypto currencies - such as Bitcoin. Supported by block chain technology, crypto currencies are most often generated in limited amount or under limited circumstances as encrypted vessels of value. They enable direct transactions, without need to know personal details of involved sides while offering total transparency of payment potential so any type of fraud can be avoided. It encourages the trust and safety, which is one more additional value besides real time and low cost transactions. Bank, having the intermediation function in transactions system, loses the reason to exist under these circumstances. 
Figure 10: Parts of the financial sector that are likely to be the most disrupted by Fintech

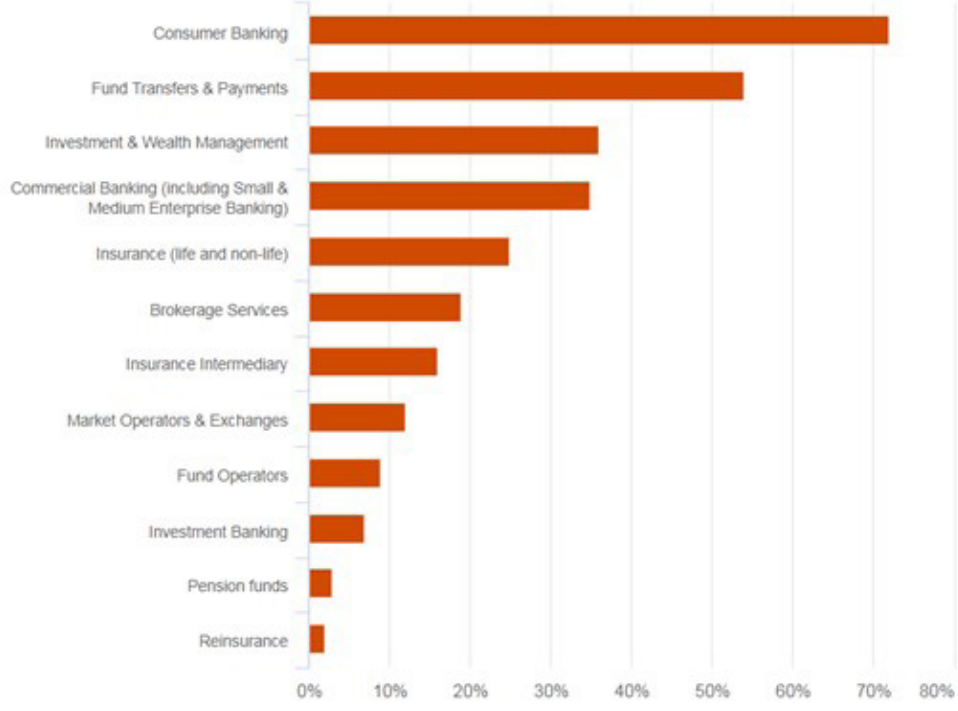

Source: PwC's Global Fintech Survey 2017

The same survey shows that payment system is the financial activities that are most at risk in moving to a Fintech company over the next 5 years:

Figure 11: Financial activities that are most at risk of moving to Fintech

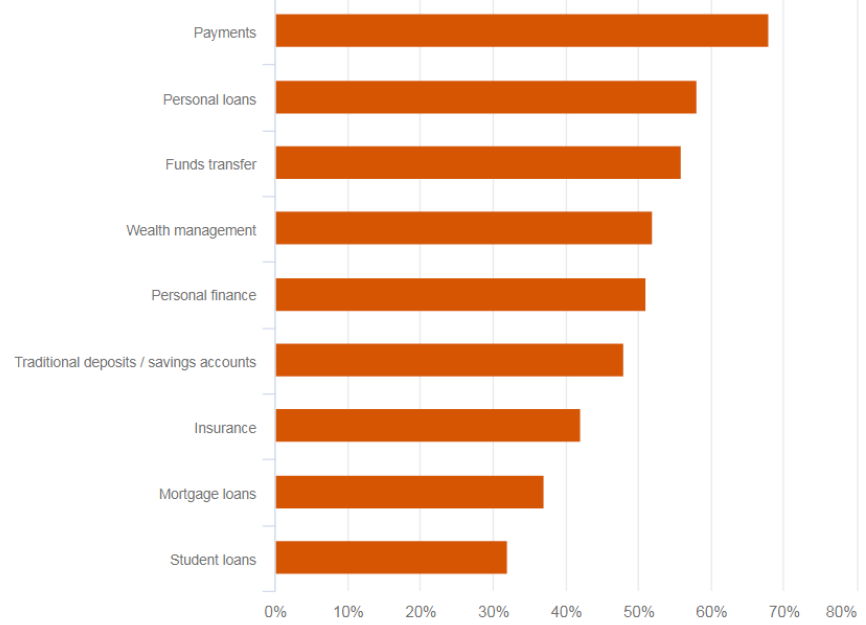

Source: PwC's Global Fintech Survey 2017

Market trends are something that also goes on hand with fintech development in payments systems. Millennials are using more and more their electronic devices for everyday activity, among which are paying bills using electronic payment systems. As 
we can see on the graph below, the use of electronic payment technologies is highly heterogeneous across European countries:

Figure 12: Use of electronic payments

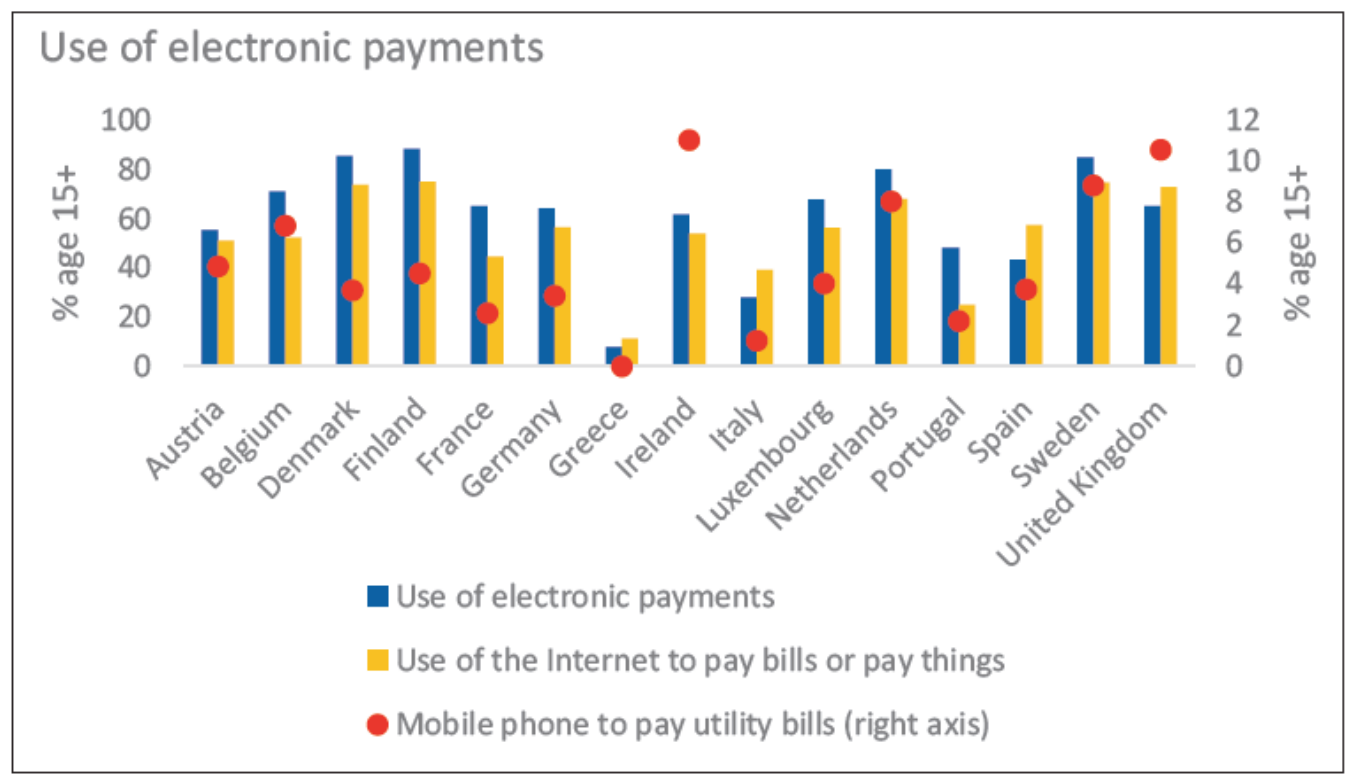

Source: http://www.worldbank.org/en/programs/globalfindex

\section{Econometric Analysis of usage of new technology and smartphones in financial transactions and payment processing}

To analyze the effects of new technology and smartphones in financial transactions and payment processing on Per capita GDP, we estimate two cross-sectional regressions including data from 150 countries. In the first cross-sectional regression, we use the 2017 per capita GDP as an dependent variable and Used the internet to pay bills or to buy something online in the past year (\% age 15+) (indpvar1), Used the internet to pay bills or to buy something online in the past year, female (\% age 15+) (infpvar2) and Used the internet to pay bills or to buy something online in the past year, male $(\%$ age $15+)$ (indvar3) as separate independent variables to show the effects of use of internet on per capita GDP. Also, by estimating separate cross-sectional regressions for male and female, we try to determine if results differ across gender. In the second regression, we try to analyze the effects of different use of mobile phone on per capita GDP. For this purpose, we analyze the effects of Paid utility bills by using a mobile phone ( $\%$ age $15+$ )(PAIDUTILITY), Received wages through a mobile phone (\% age $15+)($ RECWAGES) and Received government transfers through a mobile phone (\% age $15+)$ ( RECGOVTRAN). Table 1 shows the results of these regressions. 
Table 1: Results of the cross-sectional regressions

\begin{tabular}{|l|c|c|c|c|c|c|}
\hline & $\begin{array}{c}\text { Male and } \\
\text { Female }\end{array}$ & Male & Female & $\begin{array}{c}\text { Usage of } \\
\text { mobile } \\
\text { phones-1 }\end{array}$ & $\begin{array}{c}\text { Usage of mo- } \\
\text { bile phones-2 }\end{array}$ & $\begin{array}{c}\text { Usage of mo- } \\
\text { bile phones-3 }\end{array}$ \\
\hline INDPVAR1 & $\begin{array}{c}612.578^{* * *} \\
(31.713)\end{array}$ & $\begin{array}{c}618.985^{* * *} \\
(31.987)\end{array}$ & $\begin{array}{c}600.5716^{* * *} \\
(31.716)\end{array}$ & & & \\
\hline INDPVAR2 & - & - & - & & & \\
\hline INDPVAR3 & - & - & - & & & \\
\hline PAIDUTILITY & - & - & - & $\begin{array}{c}1570.690^{* * *} \\
(305.305)\end{array}$ & $\begin{array}{c}1407.443^{* * * *} \\
(305.668)\end{array}$ & $\begin{array}{c}1622.436^{* * *} \\
(292.839)\end{array}$ \\
\hline RECGOV- & - & - & - & $\begin{array}{c}2139.026 \\
(3409.065)\end{array}$ & $\begin{array}{c}-3045.640 \\
(2676.107)\end{array}$ & $\begin{array}{c}-2187.977^{* *} \\
(853.4361)\end{array}$ \\
\hline TRAN & - & - & - & $\begin{array}{c}-2642.515^{* *} \\
(1121.917)\end{array}$ & - & \\
\hline RECWAGES & $-2248.040^{*}$ & -1324.031 & $-3025.431^{* *}$ & $\begin{array}{c}13958.74^{* * *} \\
(1276.580)\end{array}$ & $\begin{array}{c}12604.63^{* * *} \\
(3285.641)\end{array}$ & $\begin{array}{c}14025.21^{* * *} \\
(3325.629)\end{array}$ \\
\hline constant & $(1225.398)$ & $(1189.508)$ & $(3271.465)$ \\
\hline$R^{2}$ & 0.713 & 0.713 & 0.705 & 0.282 & 0.232 & 0.279 \\
\hline
\end{tabular}

Note: Each column shows results from an ordinary least-squares regression in which the dependent variable is GDPPC2017. Standard errors are in parentheses. Significance: * p < $0.1, * * \mathrm{p}<0.05, * * * \mathrm{p}<0.01$.

The results in Table 1 indicate that except for Received government transfers through a mobile phone (\% age $15+$ ) ( RECGOVTRAN), all other independent variables do have statistically significant effect on per capita GDP. But, the effect of Received wages through a mobile phone (\% age $15+)($ RECWAGES) on per capita GDP is negative. The main reason is that, according World Bank Global Findex ( FINDEX 2017), governments make several types of payments to people — paying wages to public sector employees, distributing public sector pensions, and providing government transfers to those needing social benefits. Globally, about 100 million unbanked adults receive such payments in cash. For crucial importance in this context is an adequate cash flow management (Knežević et al., 2018).

These include 60 million women as well as 55 million adults in the poorest 40 percent of households within economies. These numbers suggest the potential for increasing account ownership by moving these payments into accounts

Technological progression enables short term wins for the new market players tech savvy companies are faster in any business plan execution (from creation of the desired product to making it available all over the world). But very few survive long enough to make a deeper market impact, mostly due to lack of basic industrial and regulatory knowledge - we can describe it as most of them is not well prepared for the challenges brought by the most regulated industry in the world. On the other side, those few that have gone from few interested customers to thousand, even million users, such as Atom bank, Monzo and Revolut, are the ones writing new banking history and showing that knowing the each and every customer needs is the crucial for sustainability on the market. 
Traditional banks can transform, no doubt about it. Data that can be found in banking systems, years and years of customer behavior, is the most valuable source of power for this transformation. While new banks had to start from scratch - finding customers, gathering their data, building products, learn about limitations by trying and failing - traditional banks have already done all of that. One can argue that this is the legacy that make the transformation slow and painful, while in fact this is a step a head compared to the all-new banks to come.

The one thing that can't be influenced but makes all the difference is time. Traditional banks have to decide how they want to be positioned in the eyes of the future generations and start act on it. Not only to match fintechs, but also to stay visible besides all-in-1 global players such as Amazon, Apple and Google.

The motive to support payment services, transactional services and all other financial services came from the need to support full cycle service from selection over purchase to payment for what is selected. Further on having AI support for tailoring specific offer per customer requires constant data enrichment in order to make better models from day to day... and even thought people today are very comfortable with enclosing private stuff to the public eye, financials were kept a secret very much. So, what better data to use in order to really get to know your customer and how better to pack the collection of those sensitive data then asking them as a side thing while customer is buying something extraordinary.

\section{Gathering and processing data}

As stated previously, data collections under the umbrella of financial sector can be used as a step up for the banks compared to new market players. Banks are built on them and newest technological advancements are changing the way these data is managed. For example, with cloud technology, high speed processing of big data volume is achievable at much lower prices - no heavy servers and specially designed and secured physical spaces with the backup of the same size and cost. Also, internet provides low cost data transfer but also data availability.

When you look at it a little closer fintechs are generally using all of the mentioned opportunities to march ahead in the new customer acquisition, because with tech evolution society also became digital and more transparent in doing any type of business (from e-commerce to bank accounts opening and management).

Now again, banks are in the position of the large data collection - but in what shape. How "clean are those data, are they kept at the same system, are they even entirely in the system or there is still something left in the "bottom drawer". So sorting this out and making it usable in a way fintechs are using these same data would require some effort.

On the other hands, fintechs are on the market for some short time, compared to the traditional banks, but if we assume that they are using the knowledge about the industry from the industry professionals it would be safe to assume that they have avoid this data quality issue at least on some level. 
If they didn't then we wouldn't be noticing such a huge difference in the processes optimization. While traditional banks are working their way towards digital transformation, new market players are already using forecast models and machine learning algorithms to personalize customer approach from defining the best channel of communication to best financial product for each individual from their portfolio. Besides building the tools to bust up the sales, fintechs are also using same technology for score cards and application processing which further goes to having end-to-end loan application processing without any interference with human.

\section{The role of regulator}

It is by far popular that banking industry is the most regulated industry and for a good reason - banks manage two most important things for people: their personal data and money.

Regulator on this new market is quite challenged to maintain stability, protect customers and promote innovation at the same time. With technology penetrating the traditional system cyber security is more and more popular subject. Cyber security issue broth new security standards that are strict in the sense of protecting both data and operations (ISO 27001 standard and GDPR, for example).

Based on Demertzis et al. (2017) the "European approach is to have the same rules and supervision for the same services independently of who is providing them". This comes from the fear of the systemic problems that might come in case of institutions fall. Latest initiatives such as PSD II and Open Banking concept as a bridge between fintechs and Banks that will enable fintechs to investigate and experiment while Banks will benefit from their actions are showing promising results. They support the innovation in somewhat controlled conditions so the regulators can also observe and decide on the appropriate regulatory enforcement to be applied on the new market players.

Permanent resolution will be hard to achieve here because regulators will have to pace up and constantly follow technological development and evolve equally fast as the innovation itself. Ideal goal would be creating the environment of choices and data control for consumers, with support for innovation development for both fintech and banks and without disturbing financial stability.

\section{Opportunities vs threats}

Various research studies discussed the number of opportunities and threats of Fintech for the financial industry from different perspectives. The main idea of these studies is to provide a comprehensive look at the expected outcomes that these potential threats and opportunities from FinTech provides for the financial markets and banking sector. The benefit of opportunities and the degree of exposure to the risks depends on many factors as the local environment, management, and global environment changes. 


\section{Opportunities}

According to the global specialized reports and studies (BCBS, 2017; Financial Stability Board, 2017; IOSCO, 2017; Peters \& Panayi, 2016) the main opportunities are:

- Greater access to capital: the new solutions in providing financing like P2P and ECF platforms, offers easier way of landing money to borrowers, especially SMEs, who do not have access to bank loans and opening new possibilities of access to equity finance.

- Cost improvement: fintech firms offer same services as the banks, but with lower transaction costs and in faster and more customized way for the clients.

- $\quad$ Tailored banking services: fintech companies have developed products that are based on customer experience, which leads to tailored service that these companies can offer to the market.

- $\quad$ Enhancement in security: new technologies like block chain and other FinTech platforms creates various methods to protect anonymity and prevent information leakage

- Increase competition: New market players competing with existing banks could eventually fragment the banking market and reduce systemic risk, leading to increased financial stability.

\section{Threats}

The Fintech risks and threats come mainly from concerns about the operational risk, compliance, liquidity and volatility of bank funding sources, and the severe competition. Based on BCBS, 2017; Financial Stability Board, 2017; IOSCO, 2017; Peters \& Panayi, 2016 the main threats are:

Risk of collapse, fraud or malpractice - "these actions can occur on the platform or some by some of its users. For example fraud can occur with parties selling (and buying) securities on the platform"

Systemic risk - "The entrance of fintech firms to the banking industry increases the complexity of the system and introduces new players which may have limited expertise and experience in managing IT risks. IT interdependencies between market players and market infrastructures could cause an IT risk event to escalate into a systemic crisis."

Operation risk - "innovative products and services may increase the complexity of financial services, making it more difficult to manage and control operational risk."

Difficulties in meeting compliance requirements - "The higher level of automation and distribution of the product or service among banks and fintech companies can result in less transparency on how transactions are executed and who has compliance responsibilities. This can create potential issues and problems especially in Anti-money laundering and countering the financing of terrorism AML/CFT obligations".

Data privacy: "The risk of not complying with data privacy rules may increase with the development of big data, more outsourcing due to tie-ups with fintech firms, and the associated competition for ownership of the customer relationship". 


\section{Conclusion}

Technology has always been at the service of the banks, but the new age sees the banking system is one of the channels for selling new technological solutions.

Bottom line is that fintech companies improve competition in financial markets, provide services that traditional financial institutions do less efficiently or do not do at all, and increase the pool of users of such services. In most cases, competition will enhance efficiency, bringing in new players on the market. According to Pazzolo, (2017) fintechs provide a more efficient way to do the same old things.

On the other side, this new competition strengthens the resilient incumbents, able to play the new game. Traditional banks are well placed to adopt technological innovations and do the old things in the new way themselves. But they will certainly have to change how they operate and do business, if they want to stay in the market that has been changing and improving day by day.

The change of the financial market as we know it is inevitable. Bottom line might very easily be that both fintechs and the traditional banks are not the ones dictating the trajectory of the future development of services in this area. New generations inventing new ways of communication every day might be the one and only variable we should look into in order to predict the future of financial or any market.

According to World Bank data (Global Findex - Opportunities for expanding financial inclusion through digital technology) "many unbanked adults receiving government payments in cash - whether government transfers or public sector wages or pensionshave the basic technology needed to receive these payments in digital form. Of the 60 million unbanked adults worldwide, who receive government transfers in cash, twothirds have a mobile phone. Majority of these adults are females, which can lead to a conclusion that the process of digitalization of state government will contribute to gender equality and increase number of females receiving various type of payments in digital form.

Global Findex data (World Bank 2017) reveal many opportunities to increase account ownership among the 1.7 billion adults who remain unbanked. The data also point to ways to leverage new products and technologies to boost the use of accounts among those who already have one".

Speed of adoption of new technologies and products depends entirely on raising the interest about it among young people that are now able to connect and communicate to each other without ever physically seeing one another. Interests of young people and their perspective of the world might be the very force that will dictate the rise and fall of many industries and markets. With the force of online communities which removed limitations such as different continents and languages any new idea can get the massive support and grow from idea to basic necessity for large groups of people in just a few hours. 
At the end, fintechs will change their services faster for sure, but whatever the traditional banks decide to do they should not forget about the power of the new generation to promote and push their needs and visions until they get whatever will make their lives better. And those are the people whose voices should be heard on the path of digital transformation.

\section{Conflict of interests}

The authors declare no conflict of interest.

\section{References:}

1. Angeloska-Dichovska, M., \& Petkovska-Mirchevska, T. (2017). Challenges of the Company in the New Economy and Development of E-business Strategy. Strategic Management, 22(2), 27-35.

2. Bruton, G., Khavul, S., Siegel, D., \& Wright, M. (2015). New financial alternatives in seeding entrepreneurship: Microfinance, crowdfunding, and peer-to-peer innovations. Entrepreneurship Theory and Practice, 39(1), 9-26.

3. Cumming, D., \& Zhang, Y. (2016). Alternative investments in emerging markets: A review and new trends. Emerging Markets Review, 29, 1-23.

4. Deloitte (2018) - Fintech by the numbers, available at: https:/www2.deloitte.com/ content/dam/Deloitte/ru/Documents/financial-services/fintech-by-the-numbers.pdf

5. Deloitte (2016) - FinTech in CEE, available at: https://www2.deloitte.com/ce/en/ pages/about-deloitte/articles/fintech-cee-region.html

6. Demertzis, M., Mombelli, G., \& Wolff, G. B. (2017). Capital Markets Union and the fintech opportunity. Bruegel Policy Contribution Issue $n^{\circ} 22 \mid$ September $_{2017}$

7. Dorfleitner, G., Hornuf, L., Schmitt, M., \& Weber, M. (2017). FinTech in Germany. Cham: Springer International Publishing.

8. Durkalic, D., \& Curcic, M. (2019). Mutual influence of the international investment position and the net government position with the banking sector of the Republic of Serbia. Ekonomika, Journal for Economic Theory and Practice and Social Issues, 65(1350-2019-2799), 95-106.

9. EY (2019) - Global FinTech Adoption Index, available at: https://assets.ey.com/ content/dam/ey-sites/ey-com/en_gl/topics/banking-and-capital-markets/ey-globalfintech-adoption-index.pdf

10. Financial Stability Bord - Monitoring of FinTech, available at: http://www.fsb.org/ what-we-do/policy-development/additional-policy-areas/monitoring-of-fintech/

11. Kate J.; (2019) - What do investor should look before investing in p2p lending, available at: https://www.quora.com/What-do-investor-should-look-beforeinvesting-in-p2p-lending

12. Knežević, S., Mitrović, A., \& Sretić, D. (2018). Specifics of reporting on cash flows in insurance companies. Hotel and Tourism Management, 6(2), 21-33. doi: $10.5937 /$ menhottur $1802029 \mathrm{~K}$ 
13. Peters, G. W., \& Panayi, E. (2016). Understanding modern banking ledgers through blockchain technologies: Future of transaction processing and smart contracts on the internet of money. In Banking beyond banks and money (pp. 239-278). Springer, Cham.

14. Pierrakis, Y., \& Collins, L. (2013). Crowdfunding: A new innovative model of providing funding to projects and businesses. Available at SSRN 2395226.

15. Pozzolo, A. F. (2017). Fintech and banking. Friends or foes?. European EconomyBanks, Regulation, and the Real Sector, Year, 3.

16. PWC (2016) - How FinTech is shaping Financial Services, Global FinTech Report

17. PWC (2017) - Global Fintech Survey, available at: https://www.pwc.com/gx/en/ industries/financial-services/fintech-survey/report/data-explorer.html

18. Todorović, V., Furtula, S., \& Durkalić, D. (2018). Measuring performance of the Serbian Banking sector using CAMELS model. TEME, 961-977.

19. World Bank (2017) - Global Findex database, available at: www.worldbank.org/en/ programs/globalfindex

20. World Bank (2017) - Global Findex - Opportunities for expanding financial inclusion through digital technology, available at: https://globalfindex.worldbank.org/ chapters/opportunities-expanding-financial-inclusion-through-digital-technology 
